\section{Inheritance of harvest index in common bean}

\section{Ricardo Andrade Pinto Júnior', Magno Antonio Patto', Emanoel Sanches Martins ${ }^{1}$ and Ângela de Fátima Barbosa Abreu ${ }^{2}$}

\begin{abstract}
The aim of this study was to verify if the harvest index (HI) of common bean is higher in modern lines, to verify if its estimate varies with the cycle of the plant and environmental conditions, and to obtain information concerning its genetic control (through diallel crossing). For this purpose, six lines were crossed in a diallel. Evaluations were carried out in three crop seasons/generations - $F_{2^{\prime}}$ $F_{3}$ and $F_{4}$. A receptacle was used to collect leaves, pods, and other plant parts that fell before harvest. Diallel analysis was performed using Griffing's method II. It found that the HI was higher in modern lines and was not affected by the cycle; the estimated $\mathrm{HI}$ heterosis was negative, indicating the occurrence of dominance in order to reduce trait expression.
\end{abstract}

Key words: Plant breeding, quantitative genetics, physiological efficiency.

\section{INTRODUCTION}

Common bean in Brazil is grown under several environmental and management conditions. It is typically cultivated by subsistence farmers with little or no use of technology up to large rural entrepreneurs who utilize all available technologies. Grain yield per area in common bean has been increasing in recent years despite reduction in crop area planted (CONAB 2017). One of the factors that has contributed significantly to the increase in grain yield is the use of improved cultivars (Vencovsky and Ramalho 2000, Qian and Zhao 2017).

The question is what changes in plants occurred that contributed to this greater efficiency. One factor that may have contributed, but has not been well studied, is the harvest index $(\mathrm{HI})$, i.e., the relationship between the dry matter of the grain and total dry matter. It is expected that most modern cultivars have a higher $\mathrm{HI}$. This higher $\mathrm{HI}$ has been confirmed in other species, such as maize (Echarte et al. 2013) and rice (Li et al. 2012); however, there is no information on common bean in this regard.

Depending on environmental conditions, especially temperature and high humidity, it is expected that plants may develop their vegetative part instead of their reproductive part, especially to compete against neighboring plants. As common bean in many regions of Brazil is sown in three distinct seasons that differ in climate conditions, a variation in the $\mathrm{HI}$ is expected to occur among seasons. Unfortunately, no reports were found concerning this question.

Common bean cultivars vary widely in the duration of their reproductive and vegetative cycles, growth habit, grain size, and other morphological traits (Ramalho and Abreu 2006, Barili et al. 2015, Nalin et al. 2017). These differences probably also affect the $\mathrm{HI}$, but there is no information available. In legumes
Crop Breeding and Applied Biotechnology 18: 252-258, 2018 Brazilian Society of Plant Breeding. Printed in Brazil http://dx.doi.org/10.1590/1984$70332018 \mathrm{v} 18 \mathrm{n} 3 \mathrm{a} 38$

70332018v18n3a38

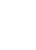


during the vegetative phase and especially during the reproductive phase, senescence of flowers, fruit, and other plant parts occurs. Normally, when estimating the $\mathrm{HI}$, the total dry matter is obtained only at the end. Consequently, $\mathrm{HI}$ values are overestimated because they do not consider the dry matter lost before harvest. For a more accurate estimate, it is important to quantify these losses throughout the cycle.

It is not enough to simply check if there is variation in the $\mathrm{HI}$ among lines, it is necessary to have information on inheritance and verify if this control varies according to environmental conditions. In this case, no reports about genetic control of the $\mathrm{HI}$ for common bean or other species were found.

In this context, the objective of this study was to determine whether the $\mathrm{HI}$ is higher in modern cultivars and whether this estimate varies according to the cycle of the lines, the gene pool of origin, and environmental conditions. An additional objective was to obtain information about inheritance of the $\mathrm{HI}$ through diallel crossing of lines with wide variation in time of obtainment, cycle, grain size, and other morphological traits.

\section{MATERIAL AND METHODS}

The experiments were conducted at the Centro de Desenvolvimento Científico e Tecnológico (Scientific and Technological Development Center) of the Universidade Federal de Lavras (UFLA) (lat $21^{\circ} 14^{\prime} \mathrm{S}$, long $45^{\circ} 59^{\prime} \mathrm{W}$ and alt $919 \mathrm{~m}$ asl), Lavras, MG.

A diallel cross was performed involving six lines, with four lines originating from the Mesoamerican gene pool (Paraná, Amarelinho, MAll-22, and Madrepérola) and two lines originating from the Andean group (Goiano Precoce and Eriparsa), all from the Universidade Federal de Lavras - UFLA germplasm bank. These lines differ not only in genetic group but in other attributes, including the number of days to flowering - the Goiano Precoce and Eriparsa lines flower at 39 days, classified as early cycle, whereas the Paraná and Amarelinho lines flower at 46 days and Madrepérola at 44 days, classified as long cycle. They also differ in when they were obtained - MAll-22 and Madrepérola were obtained recently (after 2010) and the other lines were obtained over 40 years ago (before 1970). The crosses were performed in a greenhouse.

The 21 treatments (6 parents and 15 hybrids) were evaluated in the $F_{2^{\prime}} F_{3^{\prime}}$, and $F_{4}$ generations. Sowing was carried out in February, July, and November 2015. The experimental design was a randomized block with four replications. The plots consisted of three 4-m-length rows with 15 seeds/linear meter, or 10 plants/meter after thinning. Crop treatments were performed in accordance with those adopted in the region (Ramalho et al. 2014).

The following traits were considered:

Number of days to flowering (NDF): the number of days from sowing until the time when $50 \%$ or more of the plants of the plot showed at least one open flower.

Dry plant matter "lost" before harvest: to obtain these data, a receptacle similar to that used by Izquierdo and Hosfield (1981) was placed in the center row of each plot. The receptacle was $1 \mathrm{~m}$ long, $50 \mathrm{~cm}$ wide, and $60 \mathrm{~cm}$ high, with a nylon screen with a $1 \mathrm{~mm}$ mesh (Figure 1) covering it. This receptacle was placed just after germination and emergence. Three days after flowering, leaves and other parts of the plant began to be collected in the bottom of the receptacle. This process was repeated every three days until the next harvest. In each crop season, this "lost" plant matter was dried in a laboratory oven at $65^{\circ} \mathrm{C}$ for 72 hours for determination of this biomass. At the end of each cycle, the plants with receptacles were harvested separately and also dried in a laboratory oven. The dry matter obtained during the crop cycle was added to the plant dry matter at the end of the cycle to obtain the total dry matter.

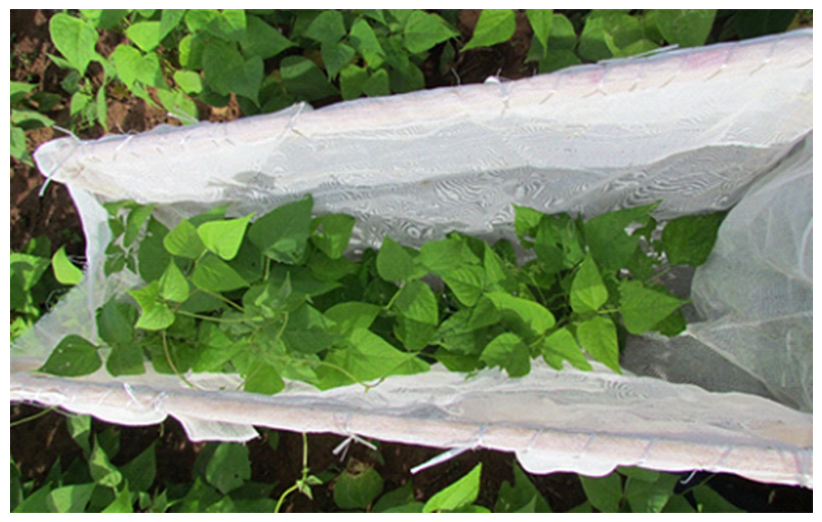

Figure 1. Nylon receptacle used for the collection of leaves, flowers, and pods that fall during the crop cycle. 
Grain dry matter: after removing the plants from the laboratory oven, the grain was weighed separately.

Harvest index: these estimates were obtained by the equation:

$$
\mathrm{HI}=\frac{\text { Total dry matter of grain }}{\text { Total dry matter of plant }}
$$

Data from the $\mathrm{HI}$ and dry weight of grain per plant (GP) were subjected to analysis of variance by generation/sowing. Later, joint analysis of the crop seasons/generations was performed, considering the model proposed by Steel et al. (1997) in which all the effects were considered fixed, except the block and error effects.

Using the averages, diallel analysis was carried out using Griffing (1956)'s method II. Correlations of the HI trait with GP and NDF ( $r_{x y}$ per season and average yields were estimated using the estimator presented by Steel et al. (1997).

\section{RESULTS AND DISCUSSION}

Analysis of the variance of GP and $\mathrm{HI}$ (data not shown) showed that the accuracies obtained for each generation were similar and of high magnitude (exceeding $87 \%$ ), indicating good experimental precision (Resende and Duarte 2007). A significant difference ( $P \leq 0.01)$ between treatments was found in all generations, for both traits. In analysis of variance of different generations for the $\mathrm{HI}$, significant differences were detected $(P \leq 0.01)$ between treatments; the same occurred for the purpose of generations. The treatment $x$ generation interaction was significant, showing that the behavior of the treatments did not coincide in the different generations (Table 1).

A possible effect of the receptacle on plant development Table 1. Summary of analysis of variance for the harvest index (HI) and grain yield per plant (GP) of common bean $\left(\mathrm{g} \mathrm{plant}^{-1}\right)$. Data from evaluation of $F_{2}, F_{3}$, and $F_{4}$ generations of a diallel cross

\begin{tabular}{lccccc}
\hline \multirow{2}{*}{ SV } & \multicolumn{3}{c}{ HI $_{(\times 100)}$} & \multicolumn{2}{c}{ GP } \\
\cline { 2 - 6 } & df & MS & $\mathbf{P}$ & MS & P \\
\hline Treatments (T) & 20 & 2.56 & 0.00 & 57.87 & 0.00 \\
GCA & 5 & 3.75 & 0.02 & 167.23 & 0.00 \\
SCA & 15 & 2.17 & 0.00 & 21.42 & 0.11 \\
Generations (G) & 2 & 5.67 & 0.00 & 703.59 & 0.00 \\
T x G & 40 & 0.49 & 0.00 & 14.62 & 0.04 \\
GCA x G & 10 & 0.76 & 0.00 & 20.51 & 0.03 \\
SCA x G & 30 & 0.41 & 0.00 & 12.66 & 0.16 \\
Error average & 180 & 0.23 & & 9.87 & \\
\hline Average & \multicolumn{3}{c}{0.33} \\
\hline
\end{tabular}
was assessed by comparing the performance of the plants within the receptacle and adjacent plants outside the receptacle. No change in the performance of the plants inside or outside the receptacle was found for number of pods and grain weight (data not shown). The harvest index, obtained from plants inside and outside the receptacle, were estimated. As expected, estimates of the $\mathrm{HI}$ in the mean of all treatments were 0.42 out of the receptacle and 0.33 in the receptacle. That is a difference of $27 \%$ in the $\mathrm{HI}$ estimate, which corresponds to the estimate of the average dry matter obtained from collections inside the receptacle involving leaves, pods, and flowers of larger magnitude. The dry matter that is uncollected contributes to an overestimation of the $\mathrm{HI}$ estimates obtained. In the treatment $x$ location interaction, data collection was not significant. It should be mentioned that in the average of all treatments, the amount of dry matter collected at the bottom of the receptacle was $21.6 \%$ of the total dry matter in the average of the three generations.

Common bean in the south of the state of Minas Gerais is grown in three seasons with sowing in February/March, July, and October/November. These growing seasons differ widely in weather conditions (Alves et al. 2015). To verify if the weather conditions affect the estimate of the $\mathrm{HI}$ in common bean, experiments were conducted in the three seasons. As in diallel, the hybrid populations were segregating, the effect of seasons confused with the generations. Therefore, even though this study highlighted the effect of generations, the environmental issue has always been present and can be enhanced considering only the information only from parents. In this case, estimation of the $\mathrm{HI}$ of the parent line in the $\mathrm{F}_{2}$ evaluation, sown in November, and the $\mathrm{F}_{3,}$ sown in February, had a higher $\mathrm{HI}(0.38)$ than the $\mathrm{HI}$ obtained in the $\mathrm{F}_{4}$, sown in July (0.33) (Table 2).

The average $\mathrm{HI}$ was 0.33 , that is, $33 \%$ of shoot dry matter is due to the grain. Reports in common bean vary, but most show the $\mathrm{HI}$ with values greater than the value obtained in this study, e.g., Zimmermann et al. (1984) obtained an $\mathrm{HI}=0.44$ and Ninou et al. (2012), an $\mathrm{HI}=0.37$. In soybean, even higher estimates can be found. Braga and Costa (1983) found 0.52. In principle, this shows that the physiological efficiency in these experiments was higher than that obtained in this study. However, they did not collect all the leaves and aborted pods that fell to the ground as was done in the present study. Therefore, the HI estimates are likely overestimated. In the case of maize, the leaf drop problem 
Table 2. Average harvest index (HI), grain yield per plant (GP) (g plant ${ }^{-1}$ ), overall average by generation, and joint analysis of the two traits. Data obtained from the $\mathrm{F}_{2}, \mathrm{~F}_{3}$, and $\mathrm{F}_{4}$ generations of the diallel cross of common bean

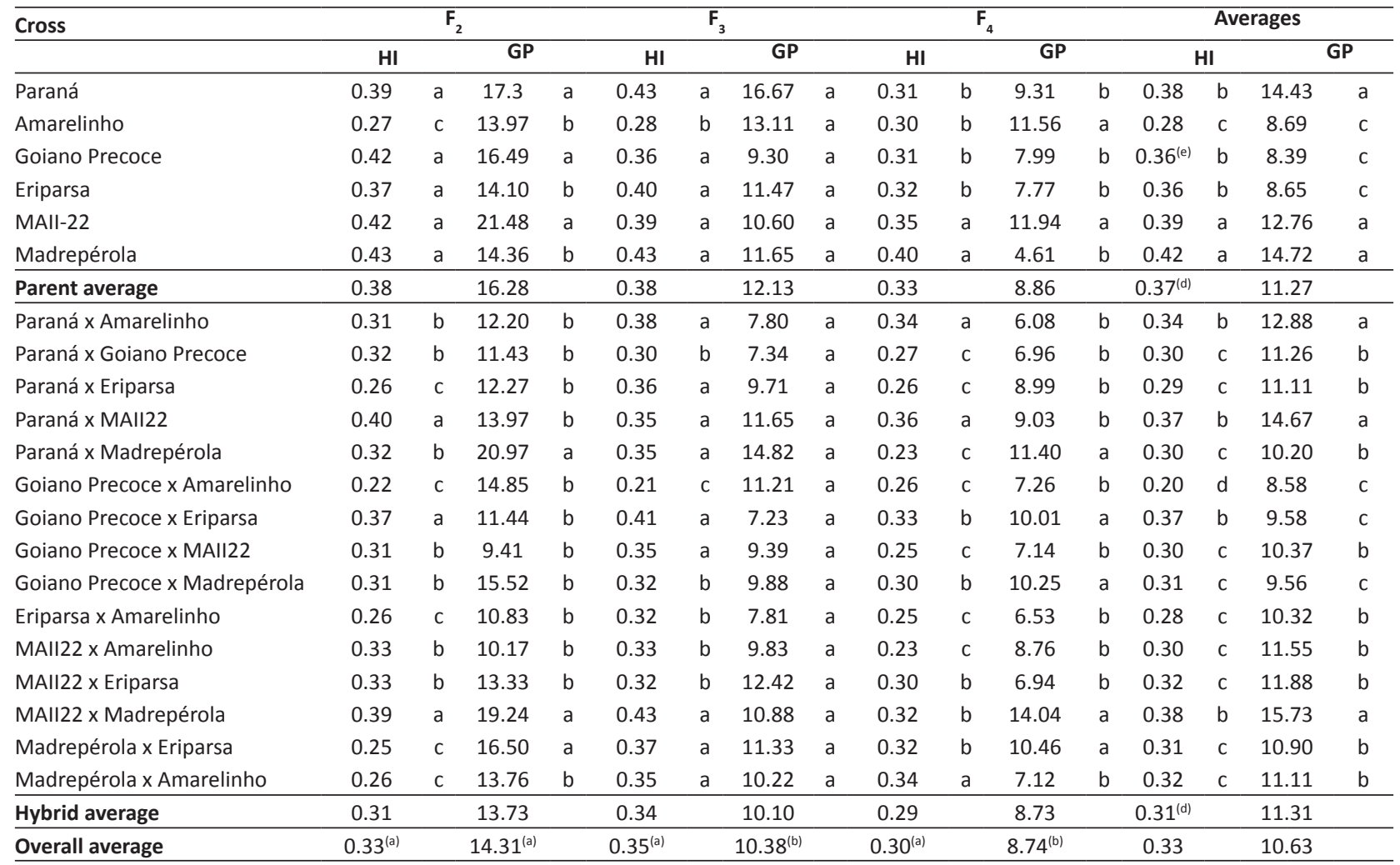

${ }^{d}$ The difference between the means of parents vs hybrids was significant $(P \leq 0.01)$.

e Mean of the Andean parents for the $\mathrm{HI}$ was 0.36 and of the Mesoamerican parents was 0.32 . (non-significant contrast $\mathrm{P}=0.80$ ). * Averages followed by the same letter in the column belong to the same group by the Scott Knott (1974) test at $5 \%$ probability. ${ }^{* *}$ For the same trait, the generation averages followed by the same uppercase letter belong to the same group by the Scott Knott (1974) test at 5\% probability.

is smaller and, as the $\mathrm{HI}$ estimates are much higher, it can be inferred that this crop has greater physiological efficiency than bean. Durães et al. (2002) and Demetrio et al. (2008), for example, obtained HI estimates ranging from 0.42 to 0.60.

Working with common beans, Costa et al. (1985) also estimated the $\mathrm{HI}$ and tried to collect all the vegetative parts of plants. What fell to the ground was collected every other day. Obviously, in this case, the procedure is not accurate, because it does not necessarily include leaves or pods that drop and remain close to the plant. They compare the HI data with periodic collection of dropped matter and without, and they found that in the latter case, the HI was overestimated.

The parent lines used differ in some agronomic traits and in origin. Initially, it should be noted that the two modern lines, MAll-22 and Madrepérola, showed, on average, a higher HI than the others (Table 2). This result shows that bean breeding programs, regardless of whether they observed the HI during selection or not, have indirectly contributed to greater efficiency in dry matter accumulation in the grain in relation to the dry matter of the vegetative part. Results like these were found in the literature regarding the bean crop. However, there are reports in maize (Echarte et al. 2013) and rice (Li et al. 2012) that modern cultivars have a higher harvest index than the older cultivars.

It was found that although Andean beans have a larger grain size than the Mesoamerican beans, the HI estimation was similar considering the average of the two groups. In the overall average, four Mesoamerican parents had an $\mathrm{HI}$ of 0.37 and the two Andean lines had an $\mathrm{HI}$ of 0.36 (Table 2). In the literature, no reference was found in this regard.

The line with the lowest HI was Amarelinho. Its cycle is not as early as G. Precoce and Eriparsa and it belongs to the Mesoamerican group, like MAll-22 and Paraná. Thus, it cannot be inferred that the HI depends on the gene pool and/ 


\section{RA Pinto Júnior et al.}

or plant cycle. Regarding the latter aspect, it is noteworthy that the estimated correlation involving the HI and NDF was of small magnitude and not significant (Table 3). However, one report was found associating precocity and the $\mathrm{HI}$, precisely in the soybean crop, and, in this case, there was a positive association between the $\mathrm{HI}$ and NDF (Pedersen and Lauer 2004).

The existence of a treatment $x$ generation interaction $(P \leq 0.05)$ (Table 1$)$ is shown by the averages of the parents and hybrids in different generations. The lack of coincidence in the performance of the lines or hybrids is evident. It was noted, however, that the Madrepérola and MAIl-22 parents were in the group of highest average treatments in all generations (Table 2).

In the diallel analysis performed using Griffing (1956)'s method, a significant difference ( $P \leq 0.05)$ was found for both general combining ability (GCA) and for specific combining ability (SCA) for the HI. The GCA x generation and SCA $x$ generation interactions were also significant $(P \leq 0.05)$. The sum of squares of the GCA was lower than the SCA, it only explained $36.6 \%$ of the total variation of treatments. In principle, these results show that dominance is a significant characteristic in manifestation of the $\mathrm{HI}$ trait. The average performance of hybrid combinations of three generations $(0.31)$ was lower than the parents (0.37), that is, a negative average heterosis. Thus, the occurrence of dominance is to reduce expression of the trait (Table 2). As the $\mathrm{HI}$ is a function of two complex traits, yield and total dry matter production, it is difficult to explain why heterosis is negative. However, the difference in the $\mathrm{HI}$ estimate of the hybrids in relation to the parents was small, only $19 \%$. No HI inheritance study was found for bean or any other species.

As expected, both parents with the highest average for the $\mathrm{HI}$ were those with the highest estimate of GCA, that is, they have good general combining ability. As expected, the opposite occurred with the Amarelinho line (Tables 2 and 4). In GCA estimates, the interaction with generations is once more well in evidence. However, as already mentioned, the MAll-22 and Madrepérola lines showed positive GCA in all generations, confirming that they contribute to increase the trait's expression in participating crosses, regardless of the generation assessed. The average of the hybrid populations, in which one of the parents was one of these lines, almost always showed larger HI estimates (Table 2), noting what has been mentioned previously. It follows that inheritance of the HI should occur with genes with both additive and dominance effects.

SCA estimates varied widely in the average of the generations and in each generation for the HI (Table 5). It is noteworthy that the MAII-22 x Madrepérola combination had a negative SCA. The SCA estimates involving the Amarelinho parent had the worst performance for the $\mathrm{HI}$; they were all positive, except for the Eriparsa $\mathrm{x}$ Amarelinho combination.

Table 3. Estimation of correlations between the harvest index $(\mathrm{HI})$ with grain yield per plant (GP) and the number of days to flowering (NDF)

\begin{tabular}{lcccc}
\hline Variables & F2 & F3 & F4 & Average \\
\hline HI and GP & $0.43^{*}$ & $0.66^{* *}$ & $0.64^{* *}$ & $0.60^{* *}$ \\
HI and NDF & -0.01 & 0.19 & 0.22 & 0.25 \\
\hline
\end{tabular}

**, * Significant at $1 \%$ and $5 \%$ probability by the t-test.
With respect to GP, the results were similar to those of the HI (Table 1). In decomposition of the Treatments source of variation, in GCA and SCA for GP, it was found that only GCA was significant. It was also found that for GP, the largest source of variation between treatments was explained by the GCA, at $72.3 \%$. This condition can, in principle, imply that there is a predominance in this trait for additive allelic interaction. This result is reinforced by

Table 4. Estimates of general combining ability (GCA) in each environment for the harvest index (HI)

\begin{tabular}{lcccc}
\hline Treatment & $\mathbf{F}_{2}$ & $\mathbf{F}_{3}$ & $\mathbf{F}_{4}$ & Average \\
\hline Paraná & 0.009 & 0.015 & -0.005 & -0.007 \\
Amarelinho & -0.049 & -0.041 & -0.012 & -0.034 \\
Goiano Precoce & 0.007 & -0.021 & -0.011 & -0.009 \\
Eriparsa & -0.013 & 0.013 & 0.002 & 0.005 \\
MAll-22 & 0.035 & 0.010 & 0.024 & 0.018 \\
Madrepérola & 0.009 & 0.025 & 0.006 & 0.008 \\
DP (Gi) & 0.008 & 0.009 & 0.009 & 0.012 \\
DP (Gi-Gj) & 0.013 & 0.013 & 0.0013 & 0.0023 \\
\hline Error & 0.0026 & 0.0028 & & \\
\hline
\end{tabular}


Inheritance of harvest index in common bean

Table 5. Estimates of specific combining ability (SCA) in each environment for the harvest index (HI)

\begin{tabular}{lllll}
\hline Cross & $\mathbf{F}_{2}$ & $\mathbf{F}_{3}$ & $\mathbf{F}_{4}$ & Average \\
\hline Paraná & 0.040 & 0.046 & 0.017 & 0.034 \\
Amarelinho & -0.027 & -0.048 & -0.017 & -0.031 \\
Goiano Precoce & -0.03 & -0.044 & -0.092 & -0.055 \\
Eriparsa & 0.013 & 0.007 & -0.066 & -0.015 \\
MAll-22 & -0.037 & -0.038 & -0.016 & -0.03 \\
Madrepérola & 0.080 & 0.026 & 0.049 & 0.052 \\
Paraná x Amarelinho & 0.019 & 0.052 & 0.054 & 0.042 \\
Paraná x Goiano Precoce & -0.067 & -0.022 & -0.036 & -0.042 \\
Paraná x Eriparsa & 0.038 & 0.008 & 0.022 & 0.023 \\
Paraná x MAll22 & -0.031 & 0.012 & 0.026 & 0.002 \\
Paraná x Madrepérola & 0.065 & 0.021 & 0.022 & 0.036 \\
Goiano Precoce x Amarelinho & 0.024 & -0.029 & 0.057 & 0.017 \\
Goiano Precoce x Eriparsa & -0.068 & -0.082 & -0.02 & -0.057 \\
Goiano Precoce x MAII22 & 0.075 & 0.048 & 0.029 & 0.051 \\
Goiano Precoce x Madrepérola & -0.023 & -0.057 & -0.006 & -0.029 \\
Eriparsa x Amarelinho & -0.008 & -0.006 & -0.038 & -0.017 \\
MAll22 x Amarelinho & 0.045 & 0.064 & 0.041 & 0.05 \\
MAll22 x Eriparsa & -0.063 & 0.007 & -0.047 & -0.034 \\
MAll22 x Madrepérola & -0.077 & -0.022 & -0.005 & -0.034 \\
Madrepérola x Eriparsa & 0.014 & 0.041 & -0.012 & 0.014 \\
Madrepérola x Amarelinho & 0.018 & 0.016 & 0.037 & 0.023 \\
\hline DP( Sii ) & 0.0187 & 0.0194 & 0.0134 & 0.0174 \\
DP( Sij ) & 0.0226 & 0.0235 & 0.0162 & 0.0211 \\
DP(Sii - Sjj) & 0.0255 & 0.0265 & 0.0184 & 0.0237 \\
DP(Sij - Sik) & 0.0338 & 0.0351 & 0.0243 & 0.0314 \\
DP(Sij - Skl) & 0.0313 & 0.0325 & 0.0225 & 0.0291 \\
\hline & & & &
\end{tabular}

Table 6. Estimates of general combining ability (GCA) in each environment for grain yield per plant (GP)

\begin{tabular}{lcccc}
\hline Treatment & $\mathbf{F}_{\mathbf{2}}$ & $\mathbf{F}_{3}$ & $\mathbf{F}_{4}$ & Average \\
\hline Paraná & 1.725 & 1.837 & 0.138 & 1.234 \\
Amarelinho & -1.288 & -0.769 & -0.678 & -0.912 \\
Goiano Precoce & -2.031 & -1.904 & -0.935 & -1.623 \\
Eriparsa & -2.123 & -0.335 & -0.549 & -1.003 \\
MAll-22 & 2.188 & 0.632 & 1.16 & 1.327 \\
Madrepérola & 1.529 & 0.54 & 0.865 & 0.978 \\
\hline SD (Gi) & 0.635 & 0.531 & 0.292 & 0.507 \\
SD (Gi-Gj) & 0.984 & 0.822 & 0.453 & 0.785 \\
\hline Error & 15.51 & 10.81 & 3.28 & \\
\hline
\end{tabular}

observing the average of the three generations; the average performance of the hybrid was similar to the average of the parents (Table 2). The results available in the literature for common bean regarding the manifestation of dominance for GP are contradictory. There are some results of studies similar to those reported here (Leal et al. 1979, Silva et al. 2004, Guilherme et al. 2014). However, others indicate that dominance occurs (Santos and Vencovsky 1986, Carvalho et al. 1999). Unlike what happened to the HI variable, three hybrid combinations (Paraná x Amarelinho, Paraná $x$ MAll22, and MAll22 $x$ Madrepérola) were classified in the highest GP group (Table 2).

Once more, the parents that stood out in the average of the three generations were Madrepérola and MAll-22, as for the HI. For the HI, the Paraná line also stood out. The others were classified in the same group (Table 2). Furthermore, in the case of GP, the parents with the highest average showed the highest estimate of GCA (Table 6). The GCA estimates clearly demonstrated the interaction with generations.

Estimates of the correlations between the $\mathrm{HI}$ and GP were all significant (Table 3). Averaging the generations, the correlation was greater than 0.6. This indicates that usually plants with a higher HI provide a higher grain yield (Donald and Hamblin 1976, Sinclair 1998). Taking the parents as a reference, the two lines with the highest HI were classified in the group with the highest average grain yield. The opposite occurred with the lines of the lowest HI group. This result reinforces what was already mentioned, that when higher grain yield is selected for, selection for a higher proportion of dry matter accumulation in the grain at the expense of the vegetative part is also indirectly selected.

\section{REFERENCES}

Alves AF, Menezes Junior JAN, Menezes VMPS, Carneiro JES, Carneiro PCS and Alves AF (2015) Genetic progress and potential of common bean families obtained by recurrent selection. Crop Breeding and Applied Biotechnology 15: 218-226.

Barili LD, Vale NM, Prado A, Carneiro JES, Silva FFE and Nascimento M (2015) Genotype-environment interaction in common bean cultivars with carioca grain, recommended for cultivation in Brazil in the last 40 years. Crop Breeding and Applied Biotechnology 15: 244-250.

Braga NR and Costa JA (1983) Avaliação de dez cultivares de soja pelo índice de colheita. Pesquisa Agropecuária Brasileira 18: 253-260.
Carvalho ACPP (1999) Capacidade de combinação para oito caracteres agronômicos em cultivares rasteiras de feijão-de-vagem. Horticultura Brasileira 17: 102-105.

CONAB - Companhia Nacional de Abastecimento (2017) Acompanhamento da safra brasileira de grãos. Editora CONAB, Brasília, 161p.

Costa JGC, Shibata JK and Miranda CS (1985) Índice de colheita em feijoeiro comum. Pesquisa Agropecuária Brasileira 6: 737-739.

Demétrio CS, Fornasieri Filho D, Cazetta JO and Cazetta DA (2008) Desempenho de híbridos de milho submetidos a diferentes espaçamentos e densidades populacionais. Pesquisa Agropecuária Brasileira 46: 1691-1697. 


\section{RA Pinto Júnior et al.}

Donald CM and Hamblin J (1976) the biological yield and harvest index of cereals as agronomic and plant breeding criteria. Advances in Agronomy 36: 361-405.

Durães FOM, Magalhães PC and Oliveira AC (2002) Índice de colheita genético e as possibilidades da genética fisiológica para melhoramento do rendimento de milho. Revista Brasileira de Milho e Sorgo 1: 33-40.

Echarte L, Nagore L, Matteo J, Robles M, Cambareri M and Maggiora D (2013) grain yield determination and resource use efficiency in maize hybrids released in different decades. In Agricultural chemistry. Publishing Company, Stoytcheva, p.19-35.

Griffing B (1956) A generalized treatment of the use of diallel crosses in quantitative inheritance. Heredity 10: 31-50.

Guilherme SR, Ramalho MAP, Abreu FB and Pereira LA (2014) Genetic control of inflorescence in common bean. Genetics and Molecular Research 13: 103-49.

Izquierdo J and Hosfield GL (1981) A collection receptacle for field abscission studies in common beans (Phaseolus vulgaris L.). Crop Science 21: 622- 625 .

Li X, Yan W, Agrama H, Jia L, Jackson A, Moldenhauer K, Yeater K, McClung A and Wu D (2012) Unraveling the complex trait of harvest index with association mapping in rice (Oryza sativa L.). Plos One 7: 100-110

Leal NR, Hamad I and Bliss FA (1979) Combining ability estimates for snap bean traits using early and advanced generations. HortScience 4: 405-415.

Nalin RS, Ramalho MAP and Carvalho BL (2017) A genetic study of traits related to canopy coverage in common bean. Crop Breeding and Applied Biotechnology 17: 313-319.

Ninou E, Tsialtas JT, Dordas CA and Papakosta DK (2012) Effect of irrigation on the relationships between leaf gas exchange related traits and yield in dwarf dry bean grown under Mediterranean conditions. Agricultural Water Management 116: 1-7.
Pedersen P and Lauer JG (2004) Response of soybean yield components to management system and planting date. Agronomy 96: 1372-1381.

Qian J and Zhao Z (2017) Estimating the contribution of new seed cultivars to increases in crop yields: a case study for corn. Sustainability 9: $1282-1283$.

Ramalho MAP and Abreu AFB (2006) Cultivares. In Vieira C, Paula Júnior TJ and Borém A (eds) Feijão. Editora UFV, Viçosa, p. 415-436.

Ramalho MAP, Abreu AFB and Guilherme SR (2014) Informações técnicas para o cultivo do feijoeiro-comum na região Central-Brasileira. FUNDECC, Lavras, 168p

Resende MDV and Duarte JB (2007) Precisão e controle de qualidade em experimentos de avaliação de cultivares. Pesquisa Agropecuária Tropical 3: 182-194.

Santos JB and Vencovsky R (1986) Controle genético de alguns componentes do porte da planta do feijoeiro. Pesquisa Agropecuária Brasileira 21: 957-963.

Sinclair TR (1998) Historical changes in harvest index and crop nitrogen accumulation. Crop Science 38: 638-643

Silva MP, Amaral Júnior AT, Rodrigues R, Daher RF, Leal NR and Schuelter AR (2004) Análise dialélica da capacidade combinatória cru feijãode-vagem. Horticultura Brasileira 22: 277-280.

Steel RGD, Torrie JH and Dickey DA (1997) Principles and procedures of statistics: a biometrical approach. $3^{\text {rd }}$ edn, McGraw Hill New York, 666p.

Vencovsky R and Ramalho MAP (2000) Contribuição do melhoramento de plantas no Brasil. In Paterniani E (ed) Agricultura brasileira e pesquisa agropecuária. Editora EMBRAPA, Brasília, p.57-89.

Zimmermann MJO, Rosielle AA and Waines JG (1984) Heritabilities of grain yield of common bean in sole crop and in intercrop with maize. Crop Science 24: 641-644. 